\title{
Pengaruh Kredit Usaha Kecil (KUK) Terhadap Perkembangan Produksi dan Tenaga Kerja Pada Usaha Kecil di Sumatera Barat
}

\author{
SELLY PRIMA DESWENI \\ Akademi sekretari dan Manajemen Persada Bunda \\ Jln. Diponegoro No. 42 Pekanbaru telp:(0761) - 40218 \\ E-mail : selly.prima@yahoo.com
}

\begin{abstract}
This study aims to analyze: (1) Effect of Micro Business Credit (KUK) on the number of Micro business production in West Sumatra. (2) Effect of Micro Business Credit (KUK) on the number of workers in West Sumatra. This type of research is descriptive and associative research, namely research that describes the research variable and finds the presence or absence of influence between independent variables and dependent variables. The type of research data is secondary data which is processed using statistical analysis. The results of this study: (1) Micro Business Credit (KUK) has a significant influence on the number of small business production in West Sumatra. This means that the greater the number of Micro Business Loans (KUK) channeled by banks, the greater the possibility that the number of micro business production will increase, (2) Micro Business Credit (KUK) has a significant influence on the number of small business workers in West Sumatra. This means that the greater the number of Micro Business Loans (KUK) channeled by banks, the greater the possibility that the number ofmicro business workers will increase. The author advises banks to increase the number of mivro Business Loans (KUK) to small entrepreneurs, so that later small entrepreneurs can increase the amount of production and use of labor, this is likely to improve the economy in West Sumatra.
\end{abstract}

Keywords: Micro Business Credit (KUK), Micro business production, labor

Sektor usaha kecil merupakan sektor usaha yang terbukti berperan penting dalam mengatasi perekonomian di Indonesia. Walaupun demikian, usaha kecil dihadapkan kepada kendala dan permasalahan antara lain dari aspek permodalan, kemampuan manajemen usaha dan kualitas sumber daya manusia yang mengelolanya. Kendala lain juga disebabkan karena sulitnya akses terhadap informasi dan sumber daya produktif seperti modal dan tekonologi, yang berakibat pada terbatasnya usaha kecil untuk berkembang.

Dalam rangka pengembangan usaha kecil ini diperlukan informasi yang lengkap, mudah dan cepat untuk diakses, terutama informasi potensi suatu sektor usaha ekonomi atau komoditas untuk dikembangkan pada suatu wilayah, faktorfaktor yang mempengaruhi pengembangannya, serta aspek pengembangan program kemitraan terpadu sektor usaha atau komoditas tersebut. Kebijakan yang mendukung usaha kecil ini juga menjadi komitmen dunia perbankan.

Hal ini dibuktikan dengan adanya berbagai program yang ditujukan kepada usaha kecil itu sendiri.

Sektor ekonomi menengah ini pada umumnya memang digarap oleh sebagian besar masyarakat menengah kebawah. Disisi lain, tingkat pendidikan Sumber Daya Manusia (SDM) yang mengelola usaha kecil ini juga berbeda, mulai dari yang berpendidikan rendah hingga yang berpendidikan tinggi. Bahkan usaha kecil juga menjadi bagian dari bisnis sambilan bagi mereka yang memiliki modal. Karena begitu banyaknya usaha kecil dan menengah yang berkembang di masyarakat yang lebih berorientasi pada tenaga kerja, justru menjadikan usaha ini sebagai wadah penyerapan tenaga kerja 
dengan tingkat pendidikan rendah sampai tingkat pendidikan tinggi.

Sehubungan dengan itu usaha kecil perlu memperoleh pembinaan yang memadai, mengingat potensi ekonomi dan sosialnya yang semakin besar. Namun dalam mengembangkan usahanya cenderung mengalami beragam permasalahan, karena masih rendahnya kualitas sumber daya manusia untuk mengembangkan usaha tersebut dan juga keterbatasan modal, sarana dan sulitnya akases terhadap lembaga keuangan, khususnya lembaga perbankan di daerahdaerah.

Begitu juga perkembangan usaha kecil menengah yang terdapat di Sumatera Barat. Setiap tahunnya perkembangan usaha kecil menengah meningkat signifikan. Ditandai dengan berbagai macam usaha kecil yang berkembang di tengah - tengah masyarakat yang mencakup berbagai bidang, mulai dari perkebunan, pertanian, kerajinan, perikanan dll. Seperti yang dijabarkan sebelumnya, usaha kecil ini kebanyakan juga dikelola oleh masyarakat menengah ke bawah dengan bermodalkan seadanya, sehinnga perkembangan usaha mereka cenderung kurang maksimal. Disisi lain, peluang usaha begitu besar namun terhalang oleh keterbatasan modal. Sehingga membuat mereka kesulitan untuk maju mengembangkan usaha.

Banyak pengusaha kecil di wilayah Sumatera Barat ini mengeluhkan bahwa sebenarnya usaha mereka telah layak untuk mendapatkan kredit perbankan. Namun pihak perbankan justru melihat mereka masih belum layak mendapatkan kucuran kredit dari bank sehingga orientasi perbankan masih masih pada pengusaha besar. Selama ini pihak perbankan cenderung hanya melirik pengusaha besar untuk mengucurkan kredit, sebaliknya banyak usaha kecil yang mengejar kredit perbankan justru sulit mendapatkannya karena ketatnya deregulasi perbankan.

Oleh karena itu, pihak perbankan harus arif dalam hal ini. Meskipun orientasinya bisnis, namun demikian harus ada sedikit hati nurani untuk mau membantu memberdayakan sektor usaha kecil yang telah menopang perekonomian Nasional selama ini, mengingat sebagian besar penduduk negeri ini hidup dan bergantung dari sektor usaha kecil tersebut.

Persepsi bank menyatakan bahwa kelemahan pengusaha kecil tersebut meliputi faktor eksteren antara lain manajemen yang kurang baik dan akses pasar yang terbatas. Adapun kendala dari faktor intern dalam penyaluran kredit adalah terbatasnya kewenangan bank cabang dalam memutuskan pemberian kredit, persyaratan kredit yang diterapkan cukup berbelit dan memakan waktu yang lama, transfer dana ke kantor pusat sehingga mengakibatkan likuiditas bank untuk disalurkan kepada pengusaha kecil.

Sedangkan kendala dari para pengusaha kecil sendiri meliputi agunan yang kurang memadai. Faktor ini dijadikan alasan oleh pihak bank dalam pemberian keputusan pemberian kredit yang lebih kecil dari pada pemohon. Selain itu kesulitan dalam mengelola usaha menjadi dasar bagi bank dalam memutuskan kredit yang akhirnya memberikan kredit pinjaman lebih kecil daripada pemohon. Kesulitan ini terkait erat dengan sumber daya pengusaha kecil yang memiliki kelemahan dalam pengelolaan manajemen dan akses pasar.

Meskipun perkembangan usaha kecil di Propinsi Sumatera Barat sempat mengalami penurunan, namun seiring pergerakan waktu perkembangan usaha kecil ini sudah memperlihatkan pertumbuhan yang semakin membaik. Dimana hal ini akan berpengaruh terhadap perkembangan nilai produksi bruto usaha kecil dan rumah tangga di Propinsi Suamtera Barat.

Akhir-akhir ini pemerintah telah memberikan kebijakan kepada pihak perbankan untuk memberikan bantuan kepada para pengusaha kecil yaitu dalam bentuk Kredit Usaha Kecil (KUK) untuk 
mengembangkan usahanya tersebut sehigga produksi dan tenaga kerja juga dapat meningkat serta perekonomian juga meningkat. Perkembangan kredit usaha kecil perbankan di Sumatera Barat adalah cenderung berfluktuasi. Selama periode 2001 - 2015 kredit usaha kecil di Sumatera Barat terus mengalami peningkatan setiap tahunnya. Rata-rata perkembangan kredit usaha kecil di Sumatera Barat adalah sebesar 28,39 \% hal ini kemungkinan disebabkan karena semakin berkembangnya usaha kecil di Sumatera Barat.

Berdasarkan latar belakang masalah seperti yang diuaraikan diatas, penulis tertarik untuk meneliti sejauh mana perkembangan Kredit Usaha Kecil terhadap perkembangan produksi dan tenaga kerja di Sumatera Barat.

\section{METODE}

Untuk menganalisa permasalahan dan mencari pemecahan masalah yang diinginkan maka dibutuhkan data akurat karena bila ada data yang diperoleh tidak memenuhi syarat maka analisa yang akan dilakukan menjadi lemah dan berakibat buruk pada pengambilan keputusan-keputusan. Adapun teknik pengumpulan data yang digunakan adalah :

Teknik ini digunakan untuk data sekunder yaitu dengan melakukan pengamatan terhadap data-data dokumenter yang dibuat oleh instansi seperti Badan Statistik Kota Padang. Penelitian ini didukung dengan cara membaca buku dan literatur lainnya yang berhubungan dengan penelitian.

Analisis ini bertujuan untuk menggambarkan apa yang ditemukan pada hasil penelitian dan memberikan informasi sesuai dengan yang diperoleh di lapangan, dengan menyajikan data dalam bentuk tabel distribusi frekwensii kemudian dilakukan analisis persentase, tendensi sentral dan dispersi serta memberikan interpretasi terhadap analisis tersebut.

Dalam melakukan analisa yang berkaitan dengan Pengaruh Kredit Usaha Kecil Terhadap (KUK) Terhadap Perkembangan Jumlah Produksi Dan Tenaga
Kerja Pada Usaha Usaha Kecil Di Sumatera Barat.

Analisis ini dilakukan dengan persamaan regresi linear sederhana. Dimana analisis ini bertujuaan untuk mengetahuai pengaruh variabel independent terhadap variabel dependen yang digunakan data numerik atau kuatitatif yang berasal dari tabulasi kuisioner penelitian .

Pengaruh variabel KUK terhadap produksi industri kecil ini dapat dirumuskan kedalam model persamaan Cobb-Douglas (Soekirno, 2015), dimana ditulis sebagai berikut:

$$
\begin{aligned}
& \mathrm{Q}=\mathrm{A} \mathrm{KUK} \\
& \text { Dimana } \\
& \text { KUK } \\
& \mathrm{KUK}=\text { Kredit Usaha Kecil } \\
& \mathrm{Q}=\text { produksi }
\end{aligned}
$$

Dalam bentuk persamaan linier di atas fungsi produksi dapat ditulis :

$\log \mathrm{Q}=\log \mathrm{A}+\mathrm{B}_{1} \log \mathrm{KUK}+\mathrm{U}$

Dimana :

Log KUK = Jumlah Kredit Usaha Kecil

Log Q = Jumlah produksi

$\mathrm{U}=$ Kesalahan

\section{HASIL}

Dalam penelitian ini terdapat dua variabel bebas yaitu jumlah produksi usaha kecil (Q) dan jumlah tenaga kerja (L) di Sumatera Barat. Dimana masing-masing variabel ini akan mempengaruhi variabel terikat yaitu Kredit Usaha Kecil (KUK).

Berikut ini nilai koefisien regresi linear sederhana KUK terhadap Q di Sumatera Barat. Berdasarkan pengolahan data sekunder dengan menggunakan program SPSS, maka diperoleh persamaan linear sederhana sebagai berikut:

$$
\begin{aligned}
\log \hat{Q} & =\log A+B_{1} \log K U K \\
\log \hat{Q} & =7.846+0.219 \log K U K
\end{aligned}
$$

Dari hasil pengolahan data dapat diketahui bahwa nilai koefisien determinasi $r^{2}$ adalah $0,300 \quad(30 \%)$. Hal ini menunjukkan bahwa sumbangan yang diberikan oleh variabel Kredit Usaha Kecil (KUK) terhadap variabel jumlah produksi usaha kecil (Q) di Sumatera Barat adalah 
sebesar $30 \%$ sementara sisanya $70 \%$ dipengaruhi oleh faktor-faktor lain yang tidak masuk ke dalam model.

Tingkat hubungan bersama-sama variabel Kredit Usaha Kecil (KUK) terhadap variabel jumlah produksi usaha kecil (Q) di Sumatera Barat sebesar 0,548 (54,8\%). Nilai konstanta jumlah produksi usaha kecil (Q) di Sumatera Barat adalah sebesar 7.846 hal ini menunjukkan bahwa tanpa adanya pengaruh Kredit Usaha Kecil (KUK) maka nilai skala produksi usaha kecil (Q) di Sumatera barat sebesar 7.846 .

Dari pengujian dapat diketahui bahwa bentuk pengaruh Kredit Usaha Kecil (KUK) terhadap jumlah produksi usaha kecil (Q) di Sumatera Barat adalah positif dengan koefisien regresi 0.219. Apabila variabel Kredit Usaha Kecil (KUK) meningkat sebesar satu persen maka variabel jumlah produksi usaha kecil (Q) di Sumatera Barat meningkat sebesar 0.219 persen. Hal ini berarti semakin besar jumlah Kredit Usaha Kecil (KUK) yang disalurkan pihak perbankan maka jumlah produksi usaha kecil (Q) di Sumatera Barat juga akan meningkat dengan asumsi cateris paribus.

Berdasarkan pengolahan data sekunder dengan menggunakan program SPSS, maka diperoleh persamaan linear sederhana sebagai berikut:

$\log \hat{L}=\log A+B_{2} \log K U K$

$\log \hat{L}=3.911+0.111 \log K U K$

Dari hasil pengolahan data dapat diketahui bahwa nilai koefisien determinasi $r$

${ }^{2}$ adalah 0.625 (62.5\%). Hal ini menunjukkan bahwa sumbangan yang diberikan oleh variabel Kredit Usaha Kecil (KUK) terhadap variabel jumlah tenaga kerja usaha kecil (L) di Sumatera Barat adalah sebesar $62.5 \%$ sementara sisanya $37.5 \%$ dipengaruhi oleh faktor-faktor lain yang tidak masuk ke dalam model.

Tingkat hubungan antara variabel Kredit Usaha Kecil (KUK) terhadap variabel jumlah tenaga kerja usaha kecil (L) di Sumatera Barat sebesar 0.791 (79.1\%). Nilai konstanta jumlah tenaga kerja usaha kecil (L) di Sumatera Barat adalah sebesar 3.911 hal ini menunjukkan bahwa tanpa adanya pengaruh Kredit Usaha Kecil (KUK) maka nilai skala tenaga kerja usaha kecil (L) di Sumatera Barat sebesar 3.911

Dapat disimpulkan juga bahwa bentuk pengaruh Kredit Usaha Kecil (KUK) terhadap jumlah tenaga kerja usaha kecil (L) di Sumatera Barat adalah positif dengan koefisien regresi 0.111. Apabila variabel Kredit Usaha Kecil (KUK) meningkat sebesar satu persen maka variabel jumlah tenaga kerja usaha kecil (L) di Sumatera Barat meningkat sebesar 0.111 persen. Hal ini berarti semakin tinggi Kredit Usaha Kecil (KUK) yang disalurkan pihak perbankan maka jumlah tenaga kerja usaha kecil (L) di Sumatera Barat juga akan meningkat dengan asumsi cateris paribus.

\section{Uji t (t-test)}

Dari pengujuian nilai $t$ yang dilakukan dengan mengguankan $t_{\text {hitung }}$ dan menggambarkan probabilitas yang dihitung dengan 0.05 dengan $\mathrm{df}=13$ maka nilai $\mathrm{t}_{\text {tabel }}$ dalam penelitian ini adalah 1.7709. untuk mengetahui apakah variabel bebas berpengaruh terhadap variabel terikat secara parsial maka diperoleh hasil sebagai berikut:

a). Hipotesa Pertama

Terdapat pengaruh yang signifikan antara jumlah Kredit Usaha Kecil (KUK) terhadap jumlah Produksi usaha kecil (Q) di Sumatera Barat.

Dapat dilihat nilai t hitung yang diperoleh $\mathrm{t}_{\text {hitung }}>\mathrm{t}_{\text {Tabel }}$ yakni $2.362>1.7709$ pada 0,05 akibatnya $\mathrm{H}_{\mathrm{o}}$ di tolak dan $\mathrm{H}_{\mathrm{a}}$ diterima sehingga hipotesis alternatif yang diajukan dalam penelitian ini diterima, bahwa terdapat pengaruh yang signifikan antara Kredit Usaha Kecil (KUK) terhadap jumlah produksi usaha kecil (Q) di Sumatera Barat. b). Hipotesa Kedua

Terdapat pengaruh yang signifikan antara jumlah Kredit Usaha Kecil (KUK) terhadap jumlah tenaga kerja usaha kecil (L) di Sumatera Barat

Nilai $\mathrm{t}$ hitung yang diperoleh $\mathrm{t}_{\text {hitung }}>\mathrm{t}_{\text {Tabel }}$ yakni $4.658>1.7709$ pada 0,05 akibatnya 
$\mathrm{H}_{\mathrm{o}}$ di tolak dan $\mathrm{H}_{\mathrm{a}}$ diterima sehingga hipotesis alternatif yang diajukan dalam penelitian ini diterima, bahwa terdapat pengaruh yang signifikan antara Kredit Usaha Kecil (KUK) terhadap jumlah tenaga kerja usaha kecil (L) di Sumatera Barat.

\section{PEMBAHASAN}

Pengaruh Kredit Usaha Kecil (KUK) Terhadap Jumlah Produksi Usaha Kecil (Q) di Sumatera Barat

Pengaruh Kredit Usaha Kecil (KUK) terhadap produksi usaha kecil di Sumatera Barat berdasarkan uji hipotesis adalah signifikan pada $\alpha=0.05, \mathrm{t}_{\text {hitung }}>\mathrm{t}_{\text {tabel }}$ yakni $2.362>1.7709$. hal ini berarti bahwa Kredit Usaha Kecil (KUK) berpengaruh signifikan terhadap jumlah produksi usaha kecil (Q) di Sumatera Barat. Semakin banyak bantuan Kredit Usaha Kecil (KUK) yang disalurkan pihak perbankan maka semakin meningkat jumlah produksi usaha kecil (Q) di Sumatera Barat dengan asumsi cateris baribus.

Dalam hal ini, berdasarkan hasil penelitian yang dilakukan terdapat pengaruh yang positif antara Kredit Usaha Kecil (KUK) terhadap jumlah produksi usaha kecil (Q) hal ini sangat berarti bagi para pengusaha usaha kecil di Sumatera Barat. Dengan demikian dapat disimpulkan bahwa semakin meningkatnya Kredit Usaha Kecil (KUK) yang disalurkan pihak perbankan maka berdampak posotif terhadap jumlah produksi usaha kecil (Q) di Sumatera Barat.

$$
\text { Kredit Usaha Kecil (KUK) }
$$

merupakan hal yang cukup berperan penting dalam pengembangan produksi usaha kecil, sebab dengan adanya bantuan kredit yang disalurkan pihak perbankan tersebut maka para pengusa usaha kecil akan dapat mengembangkan usahanya dengan baik yaitu seperti untuk meningkatkan produksi. Dengan meningkatnya produksi maka para pengusaha kecil akan lebih dapat mengembangkan usahanya serta pendapatan yang diterima oleh para pengusaha juga akan meningkat.

Jurnal Daya Saing (Vol. 5, No. 1 Februari 2019)
Pengaruh Kredit Usaha Kecil (KUK) Terhadap Jumlah Tenaga Kerja Usaha Kecil (L) di Sumatera Barat

Pengaruh Kredit Usaha Kecil (KUK) terhadap produksi usaha kecil di Sumatera Barat berdasarkan uji hipotesis adalah signifikan pada $\alpha=0.05$, $\mathrm{t}_{\text {hitung }}>\mathrm{t}_{\text {tabel }}$ yakni $4.658>1.7709$. hal ini berarti bahwa Kredit Usaha Kecil (KUK) berpengaruh signifikan terhadap jumlah tenaga kerja usaha kecil (L) di Sumatera Barat. Semakin banyak bantuan Kredit Usaha Kecil (KUK) yang disalurkan pihak perbankan maka semakin meningkat jumlah tenaga kerja usaha kecil (L) di Sumatera Barat dengan asumsi cateris baribus.

Dalam hal ini, berdasarkan hasil penelitian yang dilakukan terdapat pengaruh yang positif antara Kredit Usaha Kecil (KUK) terhadap jumlah tenaga kerja usaha kecil (L) hal ini sangat berarti bagi para pengusaha usaha kecil di Sumatera Barat. Dengan demikian dapat disimpulkan bahwa semakin meningkatnya Kredit Usaha Kecil (KUK) yang disalurkan pihak perbankan maka berdampak posotif terhadap jumlah tenaga kerja usaha kecil (L) di Sumatera Barat. Sehingga jumlah produksi usaha kecil pun juga akan meningkat, dengan demikian usaha kecil di Sumatera Barat akan dapat berkembang dengan baik karena adanya bantuan kredit dari pihak perbankan.

Dalam fungsi produksi CobbDouglass faktor-faktor yang mempengaruhi permintaan tenaga kerja adalah upah, harga dan modal. Dengan demikian .modal mempunyai pengaruh yang cukup penting dalam meningkatkan jumlah tenaga kerja, semakin tinggi modal yang diterima maka permintaan terhadap jumlah tenaga kerja juga akan mengalami peningkatan. Peningkatan terhadap jumlah tenaga kerja juga akan berpengaruh terhadap jumlah produksi.

Dengan semakin meningkatnya kredit yang disalurkan oleh perbankan kepada para pengusaha kecil maka hal ini akan berdampak terhadap perkembangan tenaga kerja, sabab dengan adanya bantuan 
kredit tersebut maka produksi akan meningkat. Dengan meningkatnya produksi maka permintaan terhadap tenaga kerja juga akan meningkat, sehingga pengangguran akan berkurang dan pertumbuhan ekonomi juga akan meningkat.

\section{SIMPULAN}

Hasil penelitian ini : (1) Kredit Usaha Kecil (KUK) mempunyai pengaruh yang signifikan terhadap jumlah produksi usaha kecil di Sumatera Barat. Artinya semakin besar jumlah Kredit Usaha Kecil (KUK) yang disalurkan pihak perbankan besar kemungkinan jumlah produksi usaha kecil akan meningkat, (2) Kredit Usaha Kecil (KUK) mempunyai pengaruh yang signifikan terhadap jumlah tenaga kerja usaha kecil di Sumatera Barat. Artinya semakin besar jumlah Kredit Usaha Kecil (KUK) yang disalurkan pihak perbankan besar kemungkinan jumlah tenaga kerja usaha kecil akan meningkat. Penulis menyarankan kepada pihak perbankan agar lebih meningkatkan jumlah Kredit Usaha Kecil (KUK) kepada para pengusaha kecil, sehingga nantinya para pengusaha kecil dapat meningkatkan jumlah produksi dan penggunaan tenaga kerja hal ini berkemungkinan dapat meningkatkan perekonomian di Sumatera Barat.

\section{DAFTAR RUJUKAN}

Astoni.2002.Analisa Faktor-Faktor Produksi Meubel di Kecamatan Lubuk Alung. Tidak Dipublikasikan (skripsi). Ekonomi. UNP Padang

Badan Pusat Statistik. (2009-2016). Sumatera Barat dalam Angka. Sumatera Barat:Padang.

Dinas Perindustrian Sumatera Barat. 2015. Data Usaha Kecil Menengah

Gujarati, Damodar,N. (2007). Dasar-Dasar Ekonometrika Edisi Ketiga. Jakarta: PT. Gelora Aksara Pratama.
Mulyadi. (2003). Ekonomi Sumber Daya Manusia. PT. RajaGarfindo Persada: Jakarta.

Nachrowi, Djalal and Hardius Usman. (2005). Penggunaan Teknik Ekonometri. Jakarta: PT. Raja Grafindo Persada.

Nazir. (2003). Metode Penelitian. Ghalia Indonesia: Jakarta.

Nicholson,Walter. (2002). Mikroekonomi Intermediate Edisi Kedelapan. Erlangga: Jakarta.

Pindyck dan Rubinfeld. 2012. Teori Ekonomi Mikro. Edisi 5.Jilid 1. Jakarta : PT. Indeks

Simanjuntak, J Payaman.1998.Pengantar Ekonomi Sumberdaya Manusia.FE UI Jakarta

Soekartawi.2003. Teori Ekonomi Produksi. Jakarta : PT. Raja Grafindo Persada

Sukirno, Sadono.2012. Pengantar Teori Ekonomi. FE-UI dengan Bina Grafika Jakarta

Sukirno, Sadono.2012. Pengantar Teori Ekonomi Mikro. FE-UI dengan Bina Grafika Jakarta

Sumodiningrat, Gunawan. 2002. Ekonometrika Pengantar. Yogyakarta: BPFE Yogyakarta. 